\title{
A green chemoselective one-pot protocol for expeditious synthesis of symmetric pyranodipyrimidine derivatives using $\mathrm{ZrOCl}_{2} . \mathbf{8} \mathrm{H}_{2} \mathrm{O}$
}

\author{
Mehdi Rimaz $^{\mathrm{a}^{*}}$, Hossein Mousavi ${ }^{\mathrm{a}}$, Mojgan Behnam ${ }^{\mathrm{a}}$ and Behzad Khalilib
}

${ }^{a}$ Department of Chemistry, Payame Noor University, PO Box 19395-3697, Tehran, Iran

${ }^{b}$ Department of Chemistry, Faculty of Sciences, University of Guilan, P.O. Box 41335-1914, Rasht, Iran

\begin{tabular}{l} 
C H R O N I C L E \\
\hline Article history: \\
Received January 21, 2016 \\
Received in revised form \\
July 10, 2016 \\
Accepted 18 August 2016 \\
Available online \\
18 August 2016 \\
\hline Keywords: \\
Lewis-acid catalysis \\
Green chemistry \\
Pyranopyrimidine \\
Arylglyoxal \\
One-pot synthesis
\end{tabular}

\begin{abstract}
A B S T R A C T
A convenient, highly efficient and time economic method has been described for the chemoand regioselective synthesis of 5-aryloyl-1,3,7,9-tetraalkyl-2,8-dithioxo-2,3,8,9-tetrahydro$1 H$-pyrano[2,3-d:6,5-d $d^{\prime}$ dipyrimidine-4,6 $(5 H, 7 H)$-diones derivatives by one-pot twocomponent reaction of 1,3-diethyl-2-thiobarbituric acid or 1,3-dimethyl-2-thiobarbituric acid with substituted arylglyoxalmonohydrates using commercially available zirconium (IV) oxydichloride octahydrate $\left(\mathrm{ZrOCl}_{2} .8 \mathrm{H}_{2} \mathrm{O}\right)$ as green Lewis acid catalyst. This method is associated with some attractive characteristics such as good selectivity, very short reaction time, high yield of products, cleaner reaction profile, no harmful by-product, cheap and environmental benign catalyst, simple experimental and work-up procedure. This procedure does not require solvent separation and purification steps such as column chromatography.
\end{abstract}

\section{Introduction}

Synthesis of required products in selective and environmentally friendly way is an enduring challenge in chemical sciences. Thus in recent times "Green Chemistry" which give us the guidelines for safer and eco-friendly method of chemical synthesis has gained significant attention both from the academia and industries. ${ }^{1-6}$ Multi-component reactions (MCRs) especially those performed in water or ethanol can help chemists to conform their methodology with the requirements of "Green Chemistry" as well as to extend libraries of heterocyclic scaffolds. ${ }^{7-15}$ Creating of highly efficient, selective, ecofriendly, and reusable catalysts is an interesting target of synthetic organic chemistry in academy and industry. ${ }^{16-21}$

$\mathrm{ZrOCl}_{2} .8 \mathrm{H}_{2} \mathrm{O}$ is a highly water-tolerant compound, which its handling does not need especial precautions. ${ }^{22-23}$ Recently, $\mathrm{ZrOCl}_{2} \cdot 8 \mathrm{H}_{2} \mathrm{O}$ has emerged as very effective catalyst for various organic reactions such as Knoevenagel condensation, ${ }^{24}$ Michael addition, ${ }^{25}$ oxidation of alcohols, ${ }^{26}$ acylation of alcohols, phenols, amines and thiols, ${ }^{27}$ aerobic N-methylation of substituted Anilines, ${ }^{28}$ esterification * Corresponding author.

E-mail address: rimaz.mehdi@gmail.com (M. Rimaz) 
of long chain carboxylic acids, ${ }^{29}$ one-pot synthesis of heterocyclic compounds, ${ }^{30-34}$ and other organic transformations.

Pyrimidine derivatives and heterocyclic annulated pyrimidines display a wide spectrum of interesting pharmacological properties (Fig. 1). ${ }^{35-42}$ The pyranopyrimidines showed a broad range of biological activities, such as antitubercular, ${ }^{43}$ antimicrobial, ${ }^{44}$ antiplatelet, ${ }^{45}$ antifungal ${ }^{46}$ and antitumor agents ${ }^{47}$ as well as antiviral activities. ${ }^{48}$ As a result, the development of efficient methods for the synthesis of these compounds is one of the most attractive fields in preparative chemistry.<smiles>Nc1nc(=O)[nH]cc1F</smiles>

Flucytosine<smiles>CCN(CC)c1cc(C)nc2ncnn12</smiles>

Trapidil<smiles>O=c1[nH]cc(N(CCCl)CCCl)c(=O)[nH]1</smiles>

Uramustine<smiles></smiles>

Floxuridine<smiles>O=c1[nH]c(=O)n(C2C[C@@H]3C[C@H](C2)C3O)cc1I</smiles>

Idoxuridine<smiles>CN(Cc1cnc2nc(N)nc(N)c2n1)c1ccc(C(=O)NC(CCC(=O)O)C(=O)O)cc1</smiles>

Methotrexate<smiles>CCn1cc(C(=O)O)c(=O)c2cnc(N3CCCC3)nc21</smiles>

Piromidic Acid

Fig. 1. Examples of some substituted pyrimidine marketed drugs.

\section{Results and Discussion}

Because of the wide use of efficient and green Lewis acid catalyst in different areas of organic chemistry ${ }^{47-55}$ and as part of our previous studies, ${ }^{56-62}$ we report herein a highly efficient and expeditious method for the chemo-and regioselective synthesis of 5-aryloyl-1,3,7,9-tetraalkyl-2,8-dithioxo-2,3,8,9tetrahydro- $1 H$-pyrano[2,3- $d: 6,5-d^{\prime}$ ]dipyrimidine-4,6(5H,7H)-dione derivatives, via an one-pot twocomponent reaction of arylglyoxalmonohydrates (1a-j) and 1,3-dimethyl-2-thiobarbituric acid (3a) or 1,3-diethyl-2-thiobarbituric acid (3b). The syntheses were carried out in the presence of catalytic amount of $\mathrm{ZrOCl}_{2} \cdot 8 \mathrm{H}_{2} \mathrm{O}$ in ethanol at room temperature as shown on the Scheme 1.

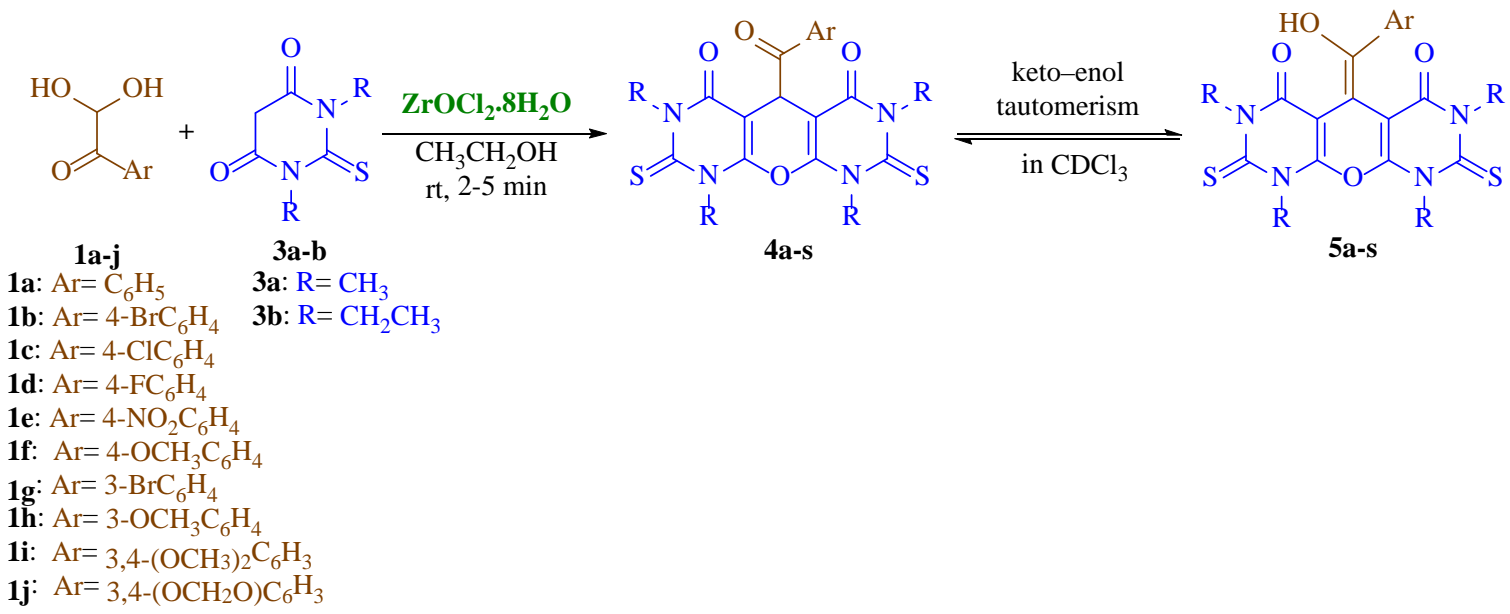

Scheme 1. $\mathrm{ZrOCl}_{2} \cdot 8 \mathrm{H}_{2} \mathrm{O}$ catalyzed synthesis of pyrano[2,3- $d: 6,5-d$ ']dipyrimidine derivatives 
Initially we have studied the reactions of phenylglyoxalmonohydrate (1a) with 1,3-dimethyl-2thiobarbituric acid (3a) or 1,3-diethyl-2-thiobarbituric acid (3b) run in the presence of $\mathrm{ZrOCl}_{2} .8 \mathrm{H}_{2} \mathrm{O}$, which was considered as green Lewis acid catalyst, in ethanol. Interestingly, the optimal catalyst loading in the synthesis of tetramethyl and tetraethyl substituted products was different. So that, in the synthesis of (4a) and (4j) were used 30 and $15 \mathrm{~mol} \%$ of $\mathrm{ZrOCl}_{2} .8 \mathrm{H}_{2} \mathrm{O}$ respectively (Table 1, entry 6 and 13). When the reaction were carried out in water, target product was not formed even after 6 hours, in all conditions tested (room temperature, $50{ }^{\circ} \mathrm{C}$ and reflux) (Table 1, entry 7, 8, 9 and 16, 17, 18).

Table 1. Optimization of the reaction conditions<smiles>[R]N1C(=O)CC(=O)N([R])C1=S</smiles>

1a

3a-b

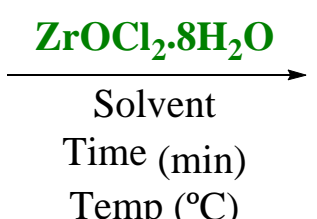

Temp $\left({ }^{\circ} \mathrm{C}\right)$<smiles>[R]n1c2c(c(=O)n([R])c1=S)C(C(=O)c1ccccc1)c1c(n([R])c(=S)n([R])c1=O)O2</smiles>

$\mathbf{4 a}$ and $\mathbf{4 j}$

\begin{tabular}{|c|c|c|c|c|c|c|c|}
\hline Entry & Solvent & $\mathrm{R}$ & Product & $\mathrm{ZrOCl}_{2} .8 \mathrm{H}_{2} \mathrm{O}, \mathrm{mol} \%$ & Temp, ${ }^{\circ} \mathrm{C}$ & Time, min & Yield, \% \\
\hline 1 & $\mathrm{CH}_{3} \mathrm{CH}_{2} \mathrm{OH}$ & $\mathrm{CH}_{3}(\mathbf{3 a})$ & $4 a$ & - & r.t. & $180^{57}$ & 83 \\
\hline 2 & $\mathrm{CH}_{3} \mathrm{CH}_{2} \mathrm{OH}$ & $\mathrm{CH}_{3}(\mathbf{3 a})$ & 4a & 5 & r.t. & 60 & 75 \\
\hline 3 & $\mathrm{CH}_{3} \mathrm{CH}_{2} \mathrm{OH}$ & $\mathrm{CH}_{3}(\mathbf{3 a})$ & 4a & 10 & r.t. & 5 & 77 \\
\hline 4 & $\mathrm{CH}_{3} \mathrm{CH}_{2} \mathrm{OH}$ & $\mathrm{CH}_{3}(\mathbf{3 a})$ & 4a & 15 & r.t. & 3 & 82 \\
\hline 5 & $\mathrm{CH}_{3} \mathrm{CH}_{2} \mathrm{OH}$ & $\mathrm{CH}_{3}(\mathbf{3 a})$ & $4 a$ & 20 & r.t. & 3 & 85 \\
\hline 6 & $\mathrm{CH}_{3} \mathrm{CH}_{2} \mathrm{OH}$ & $\mathrm{CH}_{3}(\mathbf{3 a})$ & 4a & 30 & r.t. & 3 & 91 \\
\hline 7 & $\mathrm{H}_{2} \mathrm{O}$ & $\mathrm{CH}_{3}(\mathbf{3 a})$ & $4 a$ & 20 & r.t. & 360 & - \\
\hline 8 & $\mathrm{H}_{2} \mathrm{O}$ & $\mathrm{CH}_{3}(\mathbf{3 a})$ & 4a & 20 & 50 & 360 & - \\
\hline 9 & $\mathrm{H}_{2} \mathrm{O}$ & $\mathrm{CH}_{3}(3 \mathbf{a})$ & 4a & 20 & Reflux & 360 & - \\
\hline 10 & $\mathrm{CH}_{3} \mathrm{CH}_{2} \mathrm{OH}$ & $\mathrm{CH}_{2} \mathrm{CH}_{3}(\mathbf{3 b})$ & $4 \mathbf{j}$ & - & r.t. & $180^{57}$ & 79 \\
\hline 11 & $\mathrm{CH}_{3} \mathrm{CH}_{2} \mathrm{OH}$ & $\mathrm{CH}_{2} \mathrm{CH}_{3}(3 \mathbf{b})$ & $4 j$ & 5 & r.t. & 5 & 89 \\
\hline 12 & $\mathrm{CH}_{3} \mathrm{CH}_{2} \mathrm{OH}$ & $\mathrm{CH}_{2} \mathrm{CH}_{3}(3 \mathbf{b})$ & $4 \mathbf{j}$ & 10 & r.t. & 5 & 89 \\
\hline 13 & $\mathrm{CH}_{3} \mathrm{CH}_{2} \mathrm{OH}$ & $\mathrm{CH}_{2} \mathrm{CH}_{3}(3 \mathbf{b})$ & $4 j$ & 15 & r.t. & 3 & 95 \\
\hline 14 & $\mathrm{CH}_{3} \mathrm{CH}_{2} \mathrm{OH}$ & $\mathrm{CH}_{2} \mathrm{CH}_{3}(3 \mathbf{b})$ & $4 \mathbf{j}$ & 20 & r.t. & 3 & 90 \\
\hline 15 & $\mathrm{CH}_{3} \mathrm{CH}_{2} \mathrm{OH}$ & $\mathrm{CH}_{2} \mathrm{CH}_{3}(3 \mathbf{b})$ & $4 j$ & 30 & r.t. & 3 & 90 \\
\hline 16 & $\mathrm{H}_{2} \mathrm{O}$ & $\mathrm{CH}_{2} \mathrm{CH}_{3}(3 \mathbf{b})$ & $4 j$ & 20 & r.t. & 360 & - \\
\hline 17 & $\mathrm{H}_{2} \mathrm{O}$ & $\mathrm{CH}_{2} \mathrm{CH}_{3}(3 \mathbf{b})$ & $4 j$ & 20 & 50 & 360 & - \\
\hline 18 & $\mathrm{H}_{2} \mathrm{O}$ & $\mathrm{CH}_{2} \mathrm{CH}_{3}(3 \mathbf{b})$ & $4 j$ & 20 & Reflux & 360 & - \\
\hline
\end{tabular}

Next, we probed the generality and scope of the reaction. We were pleased to find that the reaction proceeded well with a different arylglyoxalmonohydrates (1a-j) and 1,3-dimethyl-2-thiobarbituric acid (3a) or 1,3-diethyl-2-thiobarbituric acid (3b) under optimized reaction conditions to give a library of 5-aryloyl-1,3,7,9-tetraalkyl-2,8-dithioxo-2,3,8,9-tetrahydro- $1 H$-pyrano[2,3-d:6,5- $d^{\prime}$ ]dipyrimidine4,6(5H,7H)-dione derivatives (Table 1 ). The results of these reactions revealed that arylglyoxalmonohydrates bearing an electron-donating or electron-withdrawing group were well tolerated under the optimized conditions, with the corresponding pyrano[2,3- $d: 6,5-d$ ']dipyrimidine products (4a-s) being formed in excellent yields. However, the arylglyoxalmonohydrates with metaposition substituents offered lower yields than para-position substituents.

Finally, the structure of the all compounds were confirmed by means of IR, ${ }^{1} \mathrm{H}-\mathrm{NMR}$ and ${ }^{13} \mathrm{C}-\mathrm{NMR}$ spectroscopies and by comparison with available data for previously reported pyrano[2,3-d:6,5$d^{\prime}$ ]dipyrimidines. In the $\mathrm{CDCl}_{3}$ solution all pyrano[2,3-d:6,5- $\left.d^{\prime}\right]$ dipyrimidine derivatives exist as mixture of keto and enol tautomers. In the ${ }^{1} \mathrm{H}-\mathrm{NMR}$ spectra, the sharp singlet at 4.91-5.65 ppm, which belongs to $\mathrm{CH}$ of pyran ring, was present. Also broad singlet at 8.21-13.18 belongs to the $\mathrm{OH}$ group of the enol tautomer. 
A proposed mechanism of the $\mathrm{ZrOCl}_{2} .8 \mathrm{H}_{2} \mathrm{O}$ catalyzed one-pot reaction for the rapid synthesis of 4a-s is depicted on the Scheme 2. Based on literature $22-34,63$ and own observations, we believed that the carbonyl groups of arylglyoxal (2a-j) is activated by $\mathrm{ZrOCl}_{2} .8 \mathrm{H}_{2} \mathrm{O}$ to give intermediate (6) which facilitates a regioselective nucleophilic attack of the enol form of (3a-b) followed by a dehydration reaction to give (8a-s). Then, Michael addition of (7a-b) to (8a-s) catalysed by $\mathrm{ZrOCl}_{2} \cdot 8 \mathrm{H}_{2} \mathrm{O}$ led to (9a-s). The cyclization of (9a-s) and dehydration of (10a-s) afforded the final products (4a-s).

Table 2. Chemoselective synthesis of pyrano[2,3-d:6,5- $d$ ] dipyrimidine derivatives.

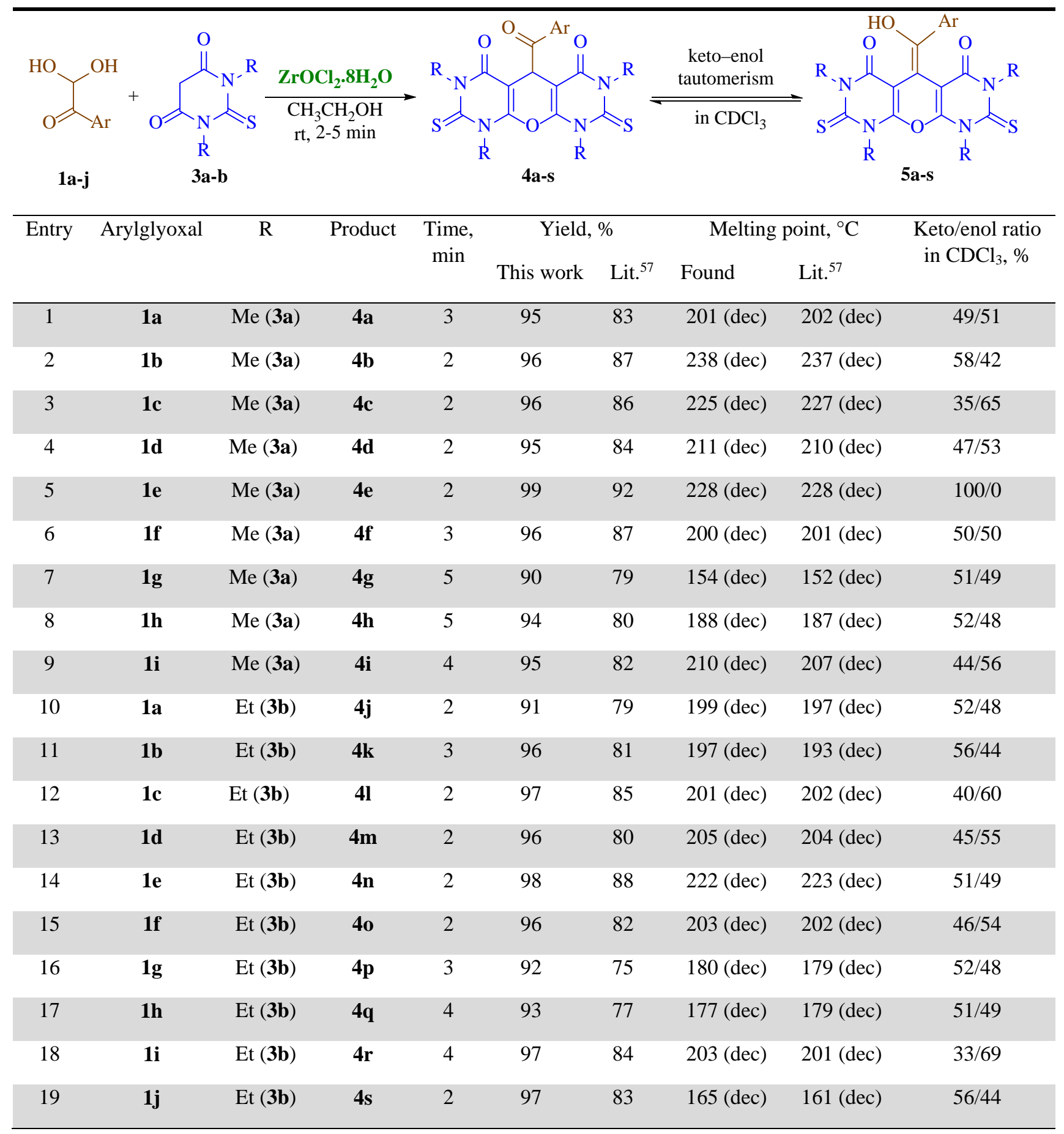




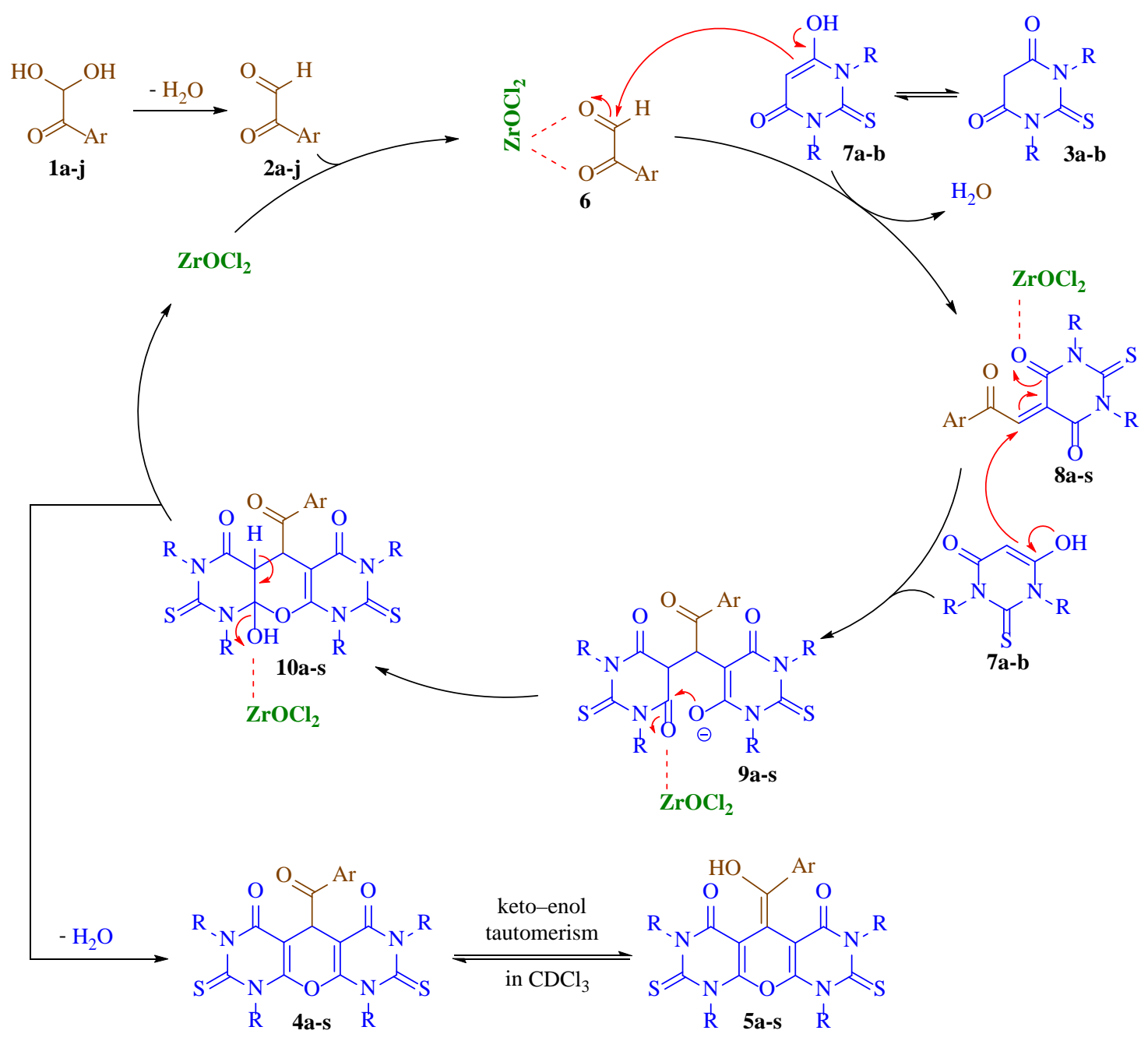

Scheme 2. Proposed mechanism for the synthesis of symmetric pyranodipyrimidine derivatives catalyzed by $\mathrm{ZrOCl}_{2} .8 \mathrm{H}_{2} \mathrm{O}$

\section{Experimental}

\subsection{General}

Melting points were measured on an Electrothermal 9200 apparatus after the recrystallization of the products from methanol. IR spectra were recorded on a Nexus-670 FT-IR spectrometer in $\mathrm{KBr} .{ }^{1} \mathrm{H}$ and ${ }^{13} \mathrm{C}$ NMR spectra were recorded on a Bruker DRX-300 Avance spectrometer at 300 and $75.5 \mathrm{MHz}$, respectively.

3.2. General procedure for the preparation of 5-aryloyl-1,3,7,9-tetramethyl-2,8-dithioxo-2,3,8,9tetrahydro-1H-pyrano[2,3-d:6,5-d'] dipyrimidine-4,6(5H,7H)-diones derivatives

A mixture of arylglyoxalmonohydrates $(1 \mathrm{mmol})$ and 1,3-dimethyl-2-thiobarbituric acid (1 mmol) in the presence of $\mathrm{ZrOCl}_{2} .8 \mathrm{H}_{2} \mathrm{O}(30 \mathrm{~mol} \%)$ in ethanol $(5 \mathrm{~mL})$ was stirred for $2-5$ minutes at room temperature. Then, the resulting precipitate was filtered and washed with water $(3 \times 5 \mathrm{~mL})$ and ethanol $(2 \times 5 \mathrm{~mL})$. The crude products were purified by recrystallization from methanol. Selected spectral data is listed below.

5-Benzoyl-1,3,7,9-tetramethyl-2,8-dithioxo-2,3,8,9-tetrahydro-1H-pyrano[2,3-d:6,5-d'] dipyrimidine4,6(5H,7H)-dione (4a) Cream powder, ${ }^{1} \mathrm{HNMR}\left(300 \mathrm{MHz}, \mathrm{CDCl}_{3}\right) \delta: 3.84-3.58\left(\mathrm{~m}, 12 \mathrm{H}, 4 \times \mathrm{CH}_{3}\right), 5.69$ (s, $1 \mathrm{H}, \mathrm{CH}$ in keto tautomer), 7.40 (t, $J=7.5 \mathrm{~Hz}, 2 \mathrm{H}, \mathrm{Ar}$ ), 7.53 (t, $J=7.5 \mathrm{~Hz}, 1 \mathrm{H}, \mathrm{Ar}$ ), 7.73 (d, $J=7.5$ $\mathrm{Hz}, 2 \mathrm{H}, \mathrm{Ar}$ ), 8.55 (br s, $1 \mathrm{H}, \mathrm{OH}$ in enol tautomer) ppm. ${ }^{13} \mathrm{CNMR}\left(75.5 \mathrm{MHz}, \mathrm{CDCl}_{3}\right.$ ) $\delta: 35.3,36.6$, 
41.5, 95.9, 127.8, 128.5, 133.0, 135.7, 162.8, 163.2, 175.4, 194.2 ppm. FT-IR (KBr) $v_{\max }$ : 2952, 2869, 2484, 1702, 1621, 1467, 1394, 1339, 1295, 1339, 1110, $789 \mathrm{~cm}^{-1}$.

2.3. General procedure for the preparation of 5-aryloyl-1,3,7,9-tetraethyl-2,8-dithioxo-2,3,8,9tetrahydro-1H-pyrano[2,3-d:6,5-d'] dipyrimidine-4,6(5H,7H)-diones derivatives.

A mixture of arylglyoxalmonohydrates $(1 \mathrm{mmol})$ and 1,3-dimethyl-2-thiobarbituric acid (1 mmol) in the presence of $\mathrm{ZrOCl}_{2} .8 \mathrm{H}_{2} \mathrm{O}(15 \mathrm{~mol} \%)$ in ethanol $(5 \mathrm{~mL})$ was stirred for $2-5$ minutes at room temperature. Then, the resulting precipitates were filtered and washed with water $(3 \times 5 \mathrm{~mL})$ and ethanol $(2 \times 5 \mathrm{~mL})$. The crude products were purified by recrystallization from methanol. Selected spectral data is listed below.

5-Benzoyl-1,3,7,9-tetraethyl-2,8-dithioxo-2,3,8,9-tetrahydro-1H-pyrano[2,3-d:6,5-d'] dipyrimidine4,6(5H,7H)-dione (4j) Cream powder, ${ }^{1} \mathrm{HNMR}\left(300 \mathrm{MHz} \mathrm{CDCl}_{3}\right) \delta: 1.12\left(\mathrm{t}, J=6.9,6 \mathrm{H}, 2 \times \mathrm{CH}_{3}\right)$, $1.36\left(\mathrm{t}, J=6.9 \mathrm{~Hz}, 6 \mathrm{H}, 2 \times \mathrm{CH}_{3}\right), 4.49$ (q, $\left.J=6.9 \mathrm{~Hz}, 4 \mathrm{H}, 2 \times \mathrm{CH}_{2}\right), 4.62$ (q, $J=6.9 \mathrm{~Hz}, 4 \mathrm{H}, 2 \times \mathrm{CH}_{2}$ ), 5.57 (s, 1H, CH in keto tautomer), 7.37 (t, $J=7.5 \mathrm{~Hz}, 2 \mathrm{H}, \mathrm{Ar}$ ), 7.49 (t, $J=7.5 \mathrm{~Hz}, 1 \mathrm{H}, \mathrm{Ar}$ ), 7.67 (d, $J$ $=7.5 \mathrm{~Hz}, 2 \mathrm{H}, \mathrm{Ar}$ ), 10.06 (br s, $1 \mathrm{H}, \mathrm{OH}$ in enol tautomer) ppm. ${ }^{13} \mathrm{CNMR}\left(75.5 \mathrm{MHz}, \mathrm{CDCl}_{3}\right.$ ) $\delta: 11.6$, 12.0, 41.5, 44.5, 44.9, 95.9, 127.6, 128.2, 132.7, 136.0, 162.3, 162.9, 174.5, 194.4 ppm. IR (KBr) $v_{\text {max: }}$ 2981, 2935, 2520, 1694, 1622, 1444, 1384, 1269, 1110, $785 \mathrm{~cm}^{-1}$.

\section{Conclusions}

In summary, we demonstrated a green, highly efficient and time-economic method for the synthesis of 5-aryloyl-1,3,7,9-tetraalkyl-2,8-dithioxo-2,3,8,9-tetrahydro-1 $H$-pyrano[2,3- $d$ :6,5- $d$ ']dipyrimidine4,6(5H,7H)-dione derivatives. This reaction was achieved by using readily available arylglyoxalmonohydrates and 1,3-dialkyl-2-thiobarbituric acid in the presence of catalytic amounts of $\mathrm{ZrOCl}_{2} .8 \mathrm{H}_{2} \mathrm{O}$ as green Lewis acid through one-pot two-component strategy in ethanol at ambient temperature.

\section{Acknowledgments}

Financial supports from the Research Council of Payame Noor University is gratefully acknowledged.

\section{References}

1 Sheldon R. A., (2012) Fundamentals of green chemistry: efficiency in reaction design. Chem. Soc. Rev., 411437-1451.

2 Beach E. S., Cui Z., and Anastas P. T. (2009) Green Chemistry: A design framework for sustainability. Energy Environ. Sci., 2 (10) 1038-1049.

3 Sankar M., Dimitratos N., Miedziak P. J., Wells P. P., Keily C. J., and Hutchings G. J. (2012) Designing bimetallic catalysts for a green and sustainable future. Chem. Soc. Rev., 41 (24) 80998139.

4 Sahu P. K., Sahu P. K., Gupta S. K., and Agarwal D. D. (2014) Chitosan: An efficient, reusable, and biodegradable catalyst for green synthesis of heterocycles. Ind. Eng. Chem. Res., 53 (6) 2085-2091.

5 Dekamin M. G., and Eslami M. (2014) Highly efficient organocatalytic synthesis of diverse and densely functionalized 2-amino- 3-cyano-4H-pyrans under mechanochemical ball milling. Green Chem., 16 (12) 4914-4921.

6 Dekamin G. M., Azimoshan M., and Ramezani L. (2013) Chitosan: a highly efficient renewable and recoverable bio-polymer catalyst for the expeditious synthesis of $\alpha$-amino nitriles and imines under mild conditions. Green Chem., 15 (3) 811-820.

7 Rotstein B. H., Zaretsky S., Vishal R., and Yudin A. K. (2014) Small heterocycles in multicomponent reactions. Chem. Rev., 114 (16) 8323-8359.

8 Shiri M. (2012) Indoles in multicomponent processes (MCPs). Chem. Rev., 112 (6) 3508-3549. 
9 Dömling A. (2006) Recent development in isocyanide based multicomponent reaction in applied chemistry. Chem. Rev., 106 (1) 17-89.

10 Dömling A., Wang W., and Wang K. (2012) Chemistry and biology of multicomponent reactions. Chem. Rev., 112 (6) 3083-3135.

11 Ramon J. D., and Yus M. (2005) Asymmetric multicomponent reactions (AMCRs): The new frontier. Angew. Chem. Int. Ed., 44 (11) 1602-1634.

12 Posner H. G. (1986) Multicomponent one-pot annulations forming 3 to 6 bonds. Chem. Rev., 86 (5) 831-844.

13 Singh M. S., and Chowdhury S. (2012) Recent developments in solvent-free multicomponent reactions: a perfect synergy for eco-compatible organic synthesis. RSC. Adv., 24547-4592.

14 Elders N., Van Der Born D., Hendrickx L. J. D., Timmer B. J. J., Krause A., Janssen E., De Kanter F. J. J., Ruijter E., andOrru R. V. A. (2009) The efficient one-pot reaction of up to eight components by the union of multicomponent reactions. Angew. Chem. Int. Ed., 48 (32) 5856-5859.

$15 \mathrm{Gu}$ Y. (2012) Multicomponent reactions in unconventional solvents: state of the art. Green Chem., 14 (8) 2091-2128.

16 Karimi B., Mobaraki A., Mirzaei H. M., Zarayee D., and Vali H. (2014) Improving the selectivity toward three-component Biginelli versus Hantzsch reactions by controlling the catalyst hydrophobic/hydrophilic surface balance. Chem. Cat. Chem., 6 (1) 212-219.

17 Karimi B., and Maleki J. (2002) Lithium triflate (LiOTf) catalyzed efficient and chemoselectivetetrahydropyranylation of alcohols and phenols under mild and neutral reaction conditions. Tetrahedron Lett., 43 (30) 5353-5355.

18 Firouzabadi H.,Sardarian A. R., Khayat Z., Karimi B.,and Tangestaninejad S. (1997) Nitrogen ligand complexes of metal chlorides as effective catalysts for the highly regio- and chemoselectivesilylation of hydroxyl groups with hexamethyldisilazane (HMDS) at room temperature. Synth.Commun., 27 (15) 2709-2719.

19 Karimi B., and Zareyee D. (2005) A high loading sulfonic acid-functionalized ordered nanoporous silica as an efficient and recyclable catalyst for chemoselectivedeprotection of tertbutyldimethylsilyl ethers. TetrahedronLett., 46 (27) 4661-4665.

20 Karimi B., Maleki A., Elhamifar D., Clark J. H., and Hunt A. J. (2010) Self-assembled organicinorganic hybrid silica with ionic liquid framework: a novel support for the catalytic enantioselective Strecker reaction of imines using $\mathrm{Yb}(\mathrm{OTf})_{3}$-pybox catalyst. Chem. Commun., 46 (37) 6947-6949.

21 Rajabi F., Luque R., Clark J. H., Karimi B., and Macquarrie D. J. (2011) A silica supported cobalt (II) Salen complex as efficient and reusable catalyst for the selective aerobic oxidation of ethyl benzene derivatives. Catal. Commun., 12 (6) 510-513.

22 Scholz J., Scholz K., and Mcquillan J. (2010) dehydration of $\mathrm{ZrOCl}_{2} .8 \mathrm{H}_{2} \mathrm{O}$. J. Phys. Chem. A., 114 (29) 7733-7741.

23 Firouzabadi H., and Jafarpour M. (2008) Some applications of zirconium (IV) tetrachloride ( $\mathrm{ZrCl}_{4}$ ) and zirconium (IV) oxydichloride octahydrate $\left(\mathrm{ZrOCl}_{2} \cdot 8 \mathrm{H}_{2} \mathrm{O}\right)$ as catalysts or reagents in organic synthesis. J. Iran. Chem. Soc., 5 (2) 159-183.

24 Akbari A., Amirabedi M., and Eftekhari-Sis B. (2012) A simplified green chemistry approach to the synthesis of carbon-carbon double bonds via knoevenagel condensation catalyzed with $\mathrm{ZrOCl}_{2} .8 \mathrm{H}_{2} \mathrm{O}$. J. Chem. Chem. Eng., 6 658-660.

25 Firouzabadi H., Iranpoor N., Jafarppour M., and Ghaderi A. (2006) $\mathrm{ZrOCl}_{2} .8 \mathrm{H}_{2} \mathrm{O}$ as a highly efficient and the moisture tolerant Lewis acid catalyst for Michael addition of amines and indoles to $\alpha, \beta$-unsaturated ketones under solvent-free conditions. J. Mol. Catal. A: Chem., 252 (1-2) 150-155.

26 Shirini F., Aolfigol M. A., and Mollarazi E. (2005) $\mathrm{KBrO}_{3} / \mathrm{ZrOCl}_{2} .8 \mathrm{H}_{2} \mathrm{O}$ : An efficient reagent system for the oxidation of alcohols. Synth. Commun., 35 (11)1541-1545.

27 Ghosh R., Maiti S., and Chakraborty A. (2005) Facile catalyzed acylation of alcohols, phenols, amines and thiols based on $\mathrm{ZrOCl}_{2} \cdot 8 \mathrm{H}_{2} \mathrm{O}$ and acetyl chloride in solution and in solvent-free conditions. Tettrahedron Lett., 46 (1) 147-151. 
28 Tayebee R., Rezaei Seresht E., Jafari F., and Rabiei S. (2013) Simple methodology for the aerobic N-Methylation of substituted anilines catalyzed by zirconium oxychloride octahydrate, $\mathrm{ZrOCl}_{2} .8 \mathrm{H}_{2} \mathrm{O}$. Ind. Eng. Chem. Res., 52 (32) 11001-11006.

29 Mantri K., Komura K., and Sugi Y. (2005) $\mathrm{ZrOCl}_{2} .8 \mathrm{H}_{2} \mathrm{O}$ catalysts for the esterification of long chain aliphatic carboxylic acids and alcohols. The enhancement of catalytic performance by supporting on ordered mesoporous silica. Green Chem., 7 (9) 677-682.

30 Rahmatpour A. (2011) $\mathrm{ZrOCl}_{2} \cdot 8 \mathrm{H}_{2} \mathrm{O}$ as a highly efficient, eco-friendly and recyclable Lewis acid catalyst for one-pot synthesis of $\mathrm{N}$-substituted pyrroles under solvent-free conditions at room temperature. Appl. Organometal. Chem., 25 (8) 588-590.

31 Rezanejade Bardajee G., Jafarpour F., and Samareh Afsari H. (2010) $\mathrm{ZrOCl}_{2} .8 \mathrm{H}_{2} \mathrm{O}$ : An efficient catalyst for rapid one-pot synthesis of 3-carboxycoumarins under ultrasound irradiation in water. Cent. Eur. J. Chem., 8 (2) 370-374.

32 Karimi S.,Karimi B., and Khodabakhshi S. (2013) Solvent-free synthesis of novel and known octahydroquinazolinones/thiones by the use of $\mathrm{ZrOCl}_{2} .8 \mathrm{H}_{2} \mathrm{O}$ as a highly efficient and reusable catalyst. J. Chin. Chem. Soc., 60 (1) 22-60.

33 Sarita M., and Ghosh R. (2011) Efficient one-pot synthesis of functionalized piperidine scaffolds via $\mathrm{ZrOCl}_{2} .8 \mathrm{H}_{2} \mathrm{O}$ catalyzed tandem reactions of aromatic aldehydes with amines and acetoacetic esters. Tettrahedron Lett., 52 (22) 2857-2861.

34 Tavakoli H. R.,Moosavi S. M., and Bazgir A. (2013) $\mathrm{ZrOCl}_{2} \cdot 8 \mathrm{H}_{2} \mathrm{O}$ as an efficient catalyst for the pseudo four-component synthesis of benzopyranopyrimidines. J. Korean. Chem. Soc., 57 (2) 260263.

35 Kappe C. O. (2000) Biologically active dihydropyrimidones of the Biginelli-type-a literature survey. Eur. J. Med. Chem., 35 (12) 1043-1052.

36 Zohdi H. F.,Rateb N. M., and Elnagdy S. M. (2011) Green synthesis and antimicrobial evaluation of some new trifluoromethyl-substituted hexahydropyrimidines by grinding. Eur. J. Med. Chem., 46 (11) 5636-5640.

37 Kamal A., Malik M. S., Bajee S., Azeeza S.,Fazel S., Ramakrishna S., Naidu V. G. M., and Vishnuwarhan M. V. P. S. (2011) Synthesis and biological evaluation of conformationally flexible as well as restricted dimers of monastrol and related dihydropyrimidones. Eur. J. Med. Chem., 46 (8) 3274-3281.

38 Singh K., Singh K., Wan B., Franzblau S., Chibale K., and Balzarini J. (2011) Facile transformation of Biginelli pyrimidin-2(1H)-ones to pyrimidines. In vitro evaluation as inhibitors of mycobacterium tuberculosis and modulators of cytostatic activity. Eur. J. Med. Chem., 46 (6) 2290-2294.

39 Singh K., Singh K., Trappanese D. M., and Moreland R. S. (2012) Highly regioselective synthesis of N-3 organophosphorous derivatives of 3,4-dihydropyrimidin-2(1H)-ones and their calcium channel binding studies. Eur. J. Med. Chem., 54 397-402.

40 Basiri A., Murugaiyah V., Osman H., Kumar R. S., Kia Y., Awang K. B., and Ali M. A. (2013) An expedient, ionic liquid mediated multi-component synthesis of novel piperidone grafted cholinesterase enzymes inhibitors and their molecular modeling study. Eur. J. Med. Chem., 67 221229.

41 Bruno-Blanch L., Galvez J., and Garcia-Domenac R. (2003) Topological virtual screening: A way to find new anticonvulsant drugs from chemical diversity. Bioorg. Med. Chem. Lett., 13 (16) 27492754.

42 Ouf N. H., Selim Y. A.,Sakran M. I., and El-din A. S. B. (2014) Synthesis of pyranochromene and pyranopyrimidine derivatives from substituted natural coumarin isolated from Ammi majus L. and their biological evaluation. Med. Chem. Res., 23 (3) 1180-1188.

43 Kamdar N. R., Haveliwala D. D., Mistry P. T., and Patel S. K. (2010) Design, synthesis and in vitro evaluation of antitubercular and antimicrobial activity of some novel pyranopyrimidines. Eur. J. Med. Chem., 45 (11) 5056-5063.

44 Ghorab M. M., and Hassan A. Y. (1998) Synthesis and antibacterial properties of new dithienyl containing pyran, pyrano[2,3-b]pyridine, pyrano[2,3-b]pyrimidine and pyridine derivatives. Phosphorus. Sulfur. Silicon., 141 (1) 251-261. 
45 Bruno O., Brullo C., Ranise A., Schenone S., Bondavalli F., Barocelli E., Ballabeni V., Chiavarini M., Tognolini M., and Impicciatore M. (2001) Synthesis and pharmacological evaluation of 2,5cycloamino-5H-[1]benzopyrano[4,3- $d$ ]pyrimidines endowed with in vitro antiplatelet activity. Bioorg. Med. Chem. Lett., 11 (11) 1397-1400.

46 Bhat A. R., Shala A. H., and Dongre R. S. (2015) Microwave assisted one-pot catalyst free green synthesis of new methyl-7-amino-4-oxo-5-phenyl-2-thioxo-2,3,4,5-tetrahydro- $1 \mathrm{H}$-pyrano[2,3d]pyrimidine-6-carboxylate as potent in vitro antibacterial and antifungal activity. J. Adv. Res., 6 (6) 941-948.

47 Abdo N. Y. M. (2015) Synthesis and antitumor evaluation of novel dihydropyrimidine, thiazolo[3,2a]pyrimidine and pyrano[2,3-d]pyrimidine derivatives. Acta. Chim. Slov., 62 (1) 168-180.

48 Shamroukh A. H.,Zaki M. E. A., Morsy E. M. H., Abdel-Motti F. M., and Abdel-Megeid F. M. E. (2007) Synthesis of pyrazolo[4',3':5,6]pyrano[2,3-d]pyrimidine derivatives for antiviral evaluation. Arch. Pharm., 340 (5) 236-243.

49 Xing S., Wang J. R. K., Cui H., Li W., and Yan H. (2015) Lewis acid promoted three-component reactions of aziridines, arenes and aldehydes: an efficient and diastereoselective synthesis of cis 1,4disubstituted tetrahydroisoquinolines. Tetrahedron, 71 (36) 6290-6299.

50 Ma G., Fujita T., and Sibi M. P. (2015) Lewis acid mediated diastereoselective intermolecular radical addition/trapping with pyrazolidinoneacrylimides. Tetrahedron Lett., 56 (23) 3571-3574.

51 Mohantry S., Roy A. K., Reddy G. S., Kumar K. P. V., Rama Devi B., Bhargavi G., and Karmakar A. C. (2015) Knoevenagel condensation of aromatic bisulfite adducts with 2,4- thiazolidinedione in the presence of Lewis acid catalysts. TetrahedronLett., 56 (20) 2564-2567.

52 Irvani N., Keshavarz M., Shojaeian Kish H. A., and Parandvar R. (2015) Tin sulfide nanoparticles supported on activated carbon as an efficient and reusable Lewis acid catalyst for three component one-pot synthesis of 4H-pyrano[2,3-c]pyrazole derivatives. Chin. J. Catal., 36 (4) 626-633.

53 Murarka S., Zhang C., Konieczynska M. D., and Seidel D. (2009) Lewis acid catalyzed formation of tetrahydroquinolines via an intramolecular redox process. Org. Lett., 11 (1)129-132.

54 North M.,Usanov D. L., and Young C. (2008) Lewis acid catalyzed asymmetric cyanohydrin synthesis. Chem. Rev., 108 (12) 5146-5226.

55 Mahrwald R. (1999) Diastereoselection in lewis-acid-mediated aldol additions. Chem. Rev., 99 (5)1095-1120.

56 Rimaz M., and Mousavi H. (2013) A one-pot strategy for regioselective synthesis of 6-aryl-3-oxo2,3- dihydropyridazine-4-carbohydrazides. Turk. J. Chem., 37 252-261.

57 Rimaz M., Rabiei H., Khalili B., and Prager R. H. (2014) An efficient one-pot two-component protocol for regio- and chemoselective synthesis of 5-aryloyl-1,3,7,9-tetraalkyl-2,8-dithioxo2,3,8,9-tetrahydro- $1 H$-pyrano[2,3-d:6,5-d']dipyrimidine-4,6(5H,7H)-diones. Aust. J. Chem., 67 (2) 283-288.

58 Rimaz M., Pourhossein P., and Khalili B. (2015) Regiospecific one-pot, combinatorial synthesis of new substituted pyrimido[4,5-c]pyridazines as potential monoamine oxidase inhibitors. Turk. J.Chem., 39 244-254.

59 Rimaz M., Mirshokraie A., Khalili B., and Motiee P. (2015) Efficient access to novel 5-aryloyl-1Hpyrano[2,3-d:6,5- $\left.d^{\prime}\right]$-dipyrimidine-2,4,6,8(3H,5H,7H,9H)-tetraones and their sulfur analogs in water. Arkivoc, v, 88-98.

60 Rimaz M. (2015) Two efficient one-pot approaches for regioselective synthesis of new 3arylpyridazino[4,3-c]quinolin-5(6H)-ones. Aust. J. Chem., 68 (10) 1529-1534.

61 Rimaz M., Jalalian Z., Mousavi H., and Prager R. H. (2016) Base organocatalyst mediated annulation of arylglyoxalmonohydrates with 2,4-dihydroxyquinoline to form new pyranodiquinolinones. Tetrahedron Lett., 57 (1) 105-109.

62 Rimaz M., Khalafy J., Mousavi H. (2016) A green organocatalyzed one-pot protocol for efficient synthesis of new substituted pyrimido[4,5- $d$ ]pyrimidinones using a Biginelli-like reaction. Res. Chem. Int., Accepted Manuscript (DOI:10.1007/s11164-016-2588-6). 
63 Rimaz M., Mousavi H., Keshavarz P., and Khalili B. (2015) $\mathrm{ZrOCl}_{2} .8 \mathrm{H}_{2} \mathrm{O}$ as a green and efficient catalyst for the expeditious synthesis of substituted 3-arylpyrimido[4,5-c]pyridazines in water. Curr. Chem. Lett., 4 (4) 159-168.

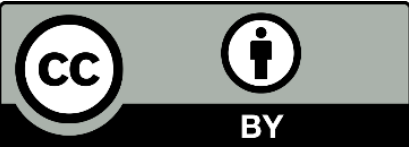

(C) 2016 by the authors; licensee Growing Science, Canada. This is an open access article distributed under the terms and conditions of the Creative Commons Attribution (CC-BY) license (http://creativecommons.org/licenses/by/4.0/). 